\title{
The Biofeedback Scapular Stabilization Exercise in Stroke Patients Effect of Muscle Activity and Function of the Upper Extremity
}

Dae-Jung Yang, Yo-Han Uhm, Je-Ho Kim

Department of Physical Therapy, Sehan University, Yeongam-gun, Jeollanam-do, Korea

Purpose: This study attempts to understand the effect of stabilization exercise of biofeedback scapular on muscle activity and functional evaluation of the upper extremity in stroke patients.

Methods: Patients were divided into two groups; a biofeedback scapular stabilization exercise group comprised of 8 patients and a taskoriented training group including another 8 patients, and 30-minute exercise was performed 5 times a week for 8 weeks. Electromyogram was used to measure muscular activity of lower trapezius, deltoid middle, and serratus anterior. Fugl-Meyer Assessment and Manual Function Test were used to evaluate functions of the muscles mentioned.

Results: Significant difference was observed in the comparison group before and after exercise in muscular activity of lower trapezius, deltoid middle, and serratus anterior, Fugl-Meyer Assessment, and Manual Function Test.

Conclusion: Therefore, we could see that biofeedback scapular stabilization exercise is more effective than task-oriented training in facilitating muscle activation and functional capacity of upper limb.

Keywords: Stroke, Biofeedback, Scapular stabilization exercise, Muscle activation

\section{서 론}

뇌졸중은 여러 원인에 의해서 장애가 생기는 질병으로 생활수준의 향상과 의학의 발전에 의해 환자의 수가 점점 증가하고 있으며, 복합 적인 결손을 가져오는 질환으로 독립적인 일상생활동작에 제한을 초래하게 된다.1-3

뇌졸중은 병변의 반대쪽 상.하지와 체간 근육이 약화되는 편마비 증상을 유발하며, 뇌졸중은 마비측의 근육 변화를 동반하여, 근육 이 가지고 있는 고유한 기능에 부정적인 영향을 미치게 된다. ${ }^{45}$ 근육 의 변화는 근력 약화, 강직, 구축 등과 밀접하게 연계되어 근육의 두 께 감소 및 근섬유의 단축 그리고 운동단위 수의 감소를 나타낸다. ${ }^{6}$ 근력 약화는 운동 기능을 저해하는 중요한 요인 중 하나로 근력 약화 를 언급하였으며, 근력 약화는 뇌졸중 환자의 일상생활동작 수행 능 력에 장애를 일으키는 중요한 원인이라고 하였다. 이와 같은 근력 약 화는 일차적으로 신경활동의 감소나 변화에 영향을 미치고, 이차적 으로는 근 활동을 감소시켜 근 활동 또한 감소됨으로 인해 근위축 및

Received Sep 16, 2015 Revised Oct 16, 2015

Accepted Oct 19, 2015

Corresponding author Je-Ho Kim

E-mail uhmyo112@naver.com
근섬유 구성비의 변화에 원인이 된다. 근력 약화는 뇌졸중 환자의 운동장애를 재활하는 데 있어 제한요인으로서, 움직임 조절에 필요 한 근육의 장력을 생성하는 능력을 감소시킨다.

뇌졸중 환자에게 근·골격계 능력은 일상생활동작을 향상시키는 데 중요한 역할을 한며, 뇌졸중 이후 척수 내림신경로의 기능 저하로 상지의 근력과 협응 능력에 약화를 보인다.8.9 상지의 근력 약화는 견 갑부에서 안정성을 감소시키며, 견갑부 주위의 근육 내 구조 변화 및 근 활동의 회복을 방해한다. ${ }^{10}$ 견갑부에서 안정성 부족과 근력 약화 는 상지의 비효율적인 움직임과 일상생활동작 수행 능력에 제한을 나타나게 한다."1 따라서, 일상생활동작에서 견갑부의 안정성이 매우 중요하며 상지에서 일어나는 움직임의 가장 큰 역할을 한다. 견갑부 는 다축성 관절로서 견부의 지지력과 안정성을 유지하기 위하여 뼈 나 인대보다 근육에 의존 하고 있는 불안정한 형태로, 이를 보완하기 위해 견갑골 주위의 여러 근육은 능동적으로 작용한다. ${ }^{12}$

뇌졸중 후 나타나는 상지의 기능 상실은 일반적인 현상이며 근력 약화나 마비, 비정상적인 근 긴장도, 연합반응, 근골격계 문제, 감각 
장애 등으로 인하여 마비측 상지의 운동 능력은 감소하고 결과적으 로 상지의 기능적 사용에 제한을 받는다.13 운동 기능 회복에 있어 하 지 기능은 상지 기능에 비해 빠르게 회복된다.13 뇌졸중 환자는 대부 분 보행 기능은 회복되지만 상지 기능은 $30-66 \%$ 에서 영구적으로 회 복되지 않고, 장애가 발생하여 일상생활동작을 스스로 수행하기 어 렵다. ${ }^{14}$ 뇌졸중 환자의 재활치료 과정 동안 마비측 하지는 독립적인 보행을 시작하면서 자연스럽게 사용 빈도가 증가하게 되는 것에 비 해, 상지의 경우 동작이 자유로운 비마비측 상지를 주로 사용하기 때 문에 마비측 상지의 기능 회복이 느리다.15 상지의 경우, 양측 모두를 사용하여야 기능적 동작이 가능한 하지와는 달리 한쪽만을 사용하 여 일상생활동작을 수행할 수 있기 때문에 마비측 기능이 다소 남아 있어도 사용을 하지 않는 경우가 빈번하여 회복에 대한 지연을 초래 할 수 있다. ${ }^{16}$ 뇌졸중 환자 중에는 근력 약화와 감각 이상으로 일상생 활동작을 수행하는데 있어서 비마비측만을 사용하는데, 마비측 상 지를 지속적으로 사용하지 않게 되면 학습된 비사용 현상이 나타나 게 되어 운동장애가 지속될 수 있다. ${ }^{17}$ 뇌졸중 환자의 일상생활로의 복귀를 위해서는 상지의 기능적 손상을 감소시킬 수 있는 치료적 접 근이 요구된다. ${ }^{18}$ 뇌졸중 환자의 상지 기능의 회복을 위한 대표적인 방법으로 운동 훈련, 과제 지향적 훈련, 기능적 전기 자극, 양측성 상 지 훈련, 강제유도운동치료 등이 있다. 하지만 이와 같은 마비측상지 의 치료적 중재는 많은 노력과 비용이 필요하고 오랜 시간 동안에 일 대일의 치료를 요구하기 때문에 계속적으로 집중력을 유지하기 어렵 다. ${ }^{19}$ 뇌졸중 환자의 기능 향상을 위한 다양한 치료적 중재방법 중 최 근 생체되먹임을 통한 훈련이 탁월한 효과가 있다고 하였다. ${ }^{20}$ 시스템 을 이용해 영상에 의한 되먹임 조절이 포함된 재활프로그램을 뇌졸 중 환자에게 적용시킨 결과, 상지의 근력과 운동 기능이 기존 물리치 료에 의한 수동적인 치료 방법보다 크게 향상됨을 보고하였다. ${ }^{21}$ 일반 적인 물리치료는 치료사의 반복적인 요구에 의해 시행되는 것이므로 환자 스스로의 동기 부여가 어렵고, 치료에 대한 흥미와 효과에 대한 기대치가 낮아 치료의 예후가 좋지 않으며, 과제지향적인 요소가 부 족하기 때문에 다양한 환경과 여러 가지 요소가 복합적으로 상호작 용하여 이루어지는 능력을 향상시키기 위해서는 많은 어려운 점이 있다고 하였다.22 이에 반해 생체되먹임을 이용한 치료는 다양한 환경 을 제공하여 감각입력의 변화를 일으켜 뇌졸중 환자의 치료효과를 높이며, 다양한 되먹임 기전을 통하여 과제 성취에 대한 동기 유발과 능동적 참여를 가능하게 하고, 환자의 기능 향상에 필요한 다양한 목 적 과제를 집중적으로 훈련시킬 수 있는 장점이 있다. ${ }^{23}$ 생체되먹임은 일상생활동작에 장애를 가진 환자에게 중요한 역할을 하는데, 시.지 각적인 요소가 사물과 공간과의 위치관계를 이해하기 어려운 뇌졸 중 환자에게 기능적 능력 개선에 효과적이라고 하였으며, 뇌졸중 환 자의 물리치료 대안으로 제시하였다. ${ }^{19}$
견갑골 안정화 운동이란, 운동 또는 조절 방해가 나타날 때에 균형 을 유지하기 위한 근골격계의 능력을 위해 상완 골두가 관절와 중심 부에 적절히 유지될 수 있고, 견갑골이 흥곽의 중립 위치에서 고정 될 수 있도록 고안 되어진 운동을 말한다. ${ }^{24}$ 이상적인 상지기능을 위해서 견갑골의 위치와 움직임을 조절하는 기능은 필수이다. 2 견갑골의 조 절된 움직임과 적절한 자세는 상지 기능에 있어 중요하며, 견갑골 안 정화 운동은 잘못된 견갑골 위치의 동적 조절과 관련된 움직임 기능 장애 교정에 사용되며 견갑대 전체에 안정성을 제공한다.10 본 연구에 서는 생체되먹임을 이용한 견갑골 안정화 운동을 이용하여 뇌졸중 환자의 상지 근육의 활성도와 기능에 미치는 효과에 대해 알아보고 자 한다.

Jung ${ }^{26}$ 은 견갑골 중재가 뇌졸중 환자들에게 상지 기능 향상에 긍 정적인 영향을 미친다고 보고하였으며, $\mathrm{Jo}^{27}$ 는 견갑골 중재가 상기 기 능과 일상생활동작 수행 능력을 향상시킨다고 보고하였다. Jung ${ }^{28}$ 은 견갑골 안정화 운동이 어깨 통증증후군 환자들의 상지 근활성도에 영향을 미친다고 보고하였다. 뇌졸중 환자의 상지 기능 회복을 위한 다양한 재활방법들이 연구되고 있는 가운데, 견갑골에 직접적인 자 극을 통한 연구들은 미비한 실정이다. 본 연구의 목적은 생체되먹임 을 이용한 견갑골 안정화 운동이 상지에 어떠한 영향을 미치는지 알 아보고자 뇌졸중 환자를 대상으로 상지의 근 활성도와, 상지 기능 평 가를 통해 새로운 치료 가능성을 제시하자고 한다.

\section{연구방법}

\section{1. 연구대상}

본 연구는 2014년 9월부터 발병일이 6개월 이상 1년 미만인 자 30명을 대상으로 하였으며, 연구의 참여기준에 적합한 자로 본인 또는 보호 자에게 본 연구의 내용과 목적을 충분히 설명하고 참여 동의서를 받 은 후 진행하였다. 연구 대상자의 참여기준은 다음과 같이 선정하였 다. 마비측 상지가 Bruunstrom 팔과 손의 회복 단계 3 단계 이상인 자, 실험에 영향을 줄 수 있는 근골격계 질환이 없으며, 신경학적 검사로 청각, 전정, 안구 손상이 없는 자, 마비측 무시 증상이 없고, 지시하는 내용을 이해하고 따를 수 있는 자로 한국형 간이정신 상태검사(Minimental State Examinaton-K)에서 24점 이상으로 의사소통과 이해가 가능한 자로 평가 시에 충분히 지시에 따라줄 수 있는 자를 대상으 로 하였다. 실험군 15 명과 대조군 15 명은 무작위 임의 선정되었으며 연구 대상자의 일반적 특성은 Table 1 과 같다.

\section{2. 실험방법}

\section{1) 생체되먹임}

실험군은 E-LINK system (Biometrics Inc, United Kingdom)의 Myo-Ex 
를 이용하여 견갑골 안정화 운동을 시행하였다(Figuer 1A). 대조군은 과제지향적 운동을 시행하였다. 과제지향적 운동 20 개의 과제는 분 무기 사용하기, 지갑에 카드 넣고 빼기, 먼지떨이기로 청소하기, 휴대 전화로 전화하기, 문 열고 잠그기, 물 따르고 마시기, 머리카락 정리하 기, 두루마리 화장기 끊기, 수도꼭지 사용하기, 가위질 하기, 비누로 손 씻기, 운동화 끈 끼워 넣기, 빨래 접기, 병뚜껑 열고 닫기, 용기 뚜껑 닫기, 콘센트 끼우고 빼기, 지퍼 열고 잠그기, 과도로 과일 자르기, 책 장 넘기기, 키보드 마우스 조작하기로 구성되어 있다.

생체되먹임 견갑골 안정화 운동을 위해 E-LINK system의 Myo-Ex 를 사용하였다(Figuer 1B). E-LINK system은 상.하지의 치료적 운동 을 위해 컴퓨터를 이용한 프로그램화된 단계별 운동을 제공한다. ELINK system의 Myo-Ex는 근육이 수축할 때 근육 내에서 발생되는 전 기적 작용을 피부 표면에 부착된 전극을 사용하여 측정할 수 있으며, 근육의 활동이나 움직임의 정도를 이와 연결된 모니터 화면에서 보 여준다. E-LINK 운동 소프트웨어는 19개의 운동 프로그램으로 구성 되어 있으며, 운동 구성 요소는 환자의 상태에 따라 단계별로 치료사 에 의해 준비된다. 기록전극(recording electrode)의 부착 부위는 마비 측의 아래등세모근의 중심부에 부착하였으며, 피부의 발생하는 전기 적 간섭 현상을 막아주는 접지전극(ground electrode)은 비마비측 손 목에 부착하였다(Figuer 2). 근육에서 발생하는 전기적 작용으로 활 동 구성 요소의 게임을 조절할 수 있고, 대상자가 생체되먹임 신호를

Table 1. General characteristic of subjects

\begin{tabular}{lccc}
\hline Characteristic & $\begin{array}{c}\text { Experimental group } \\
\text { Mean } \pm \text { SD }\end{array}$ & $\begin{array}{c}\text { ControlGroup } \\
\text { Mean } \pm \text { SD }\end{array}$ & $\mathrm{p}^{*}$ \\
\hline Number & 15 & 15 & \\
Age (year) & $55.1 \pm 4.2$ & $55.0 \pm 3.1$ & 0.806 \\
Stroke duration (month) & $9.9 \pm 1.2$ & $9.3 \pm 2.1$ & 0.914 \\
Sex (male/female) & $9 / 6$ & $8 / 7$ & 0.732 \\
Paretic side (right/left) & $6 / 9$ & $5 / 10$ & 0.697 \\
\hline
\end{tabular}

${ }^{*}$ p: Independent t-test.

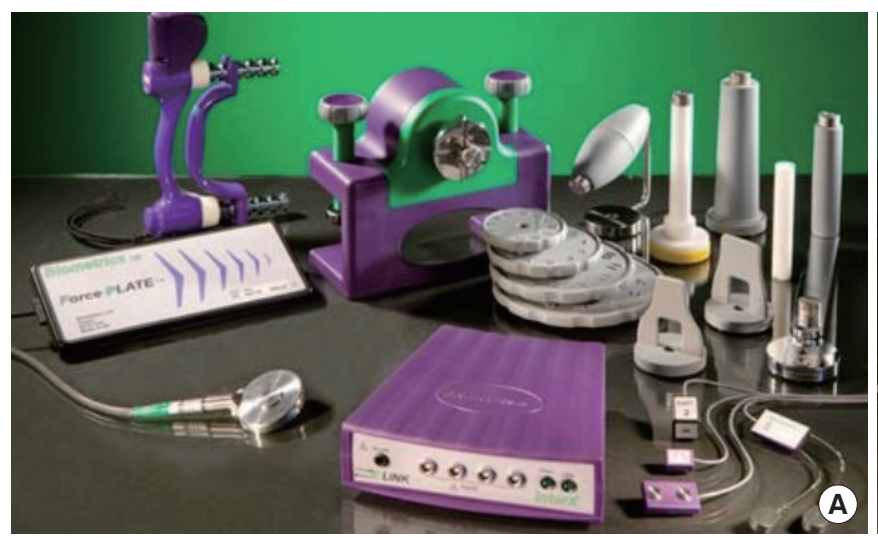

쉽게 확인할 수 있도록 모니터는 앞에 두었으며, 수축시간은 3초 휴식 시간은 1 초로 하여 실시하였다. 총 4 가지 중재 훈련 과제는 축구 골 넣기 게임(soccer activity mudules), 바나나 따는 원숭이 게임(monkeys activity modules), 지구 모형 따라가기 게임(eclipse activity modules), 스 키활강 게임(Downhill activity modules)으로 구성되어 있다. 아래등세 모근은 안정성과 운동성에 주요한 역할을 하며, 견관절 기능에 필수 적인 근육이다. ${ }^{10}$

\section{2) 견갑골 안정화 운동}

견갑골 안정화 운동 프로토콜은 Cools ${ }^{10}$ 의 연구를 바탕으로 견갑골 안정화 외회전 운동, 견갑골 안정화 굴곡 운동, 견갑골 안정화 수평외

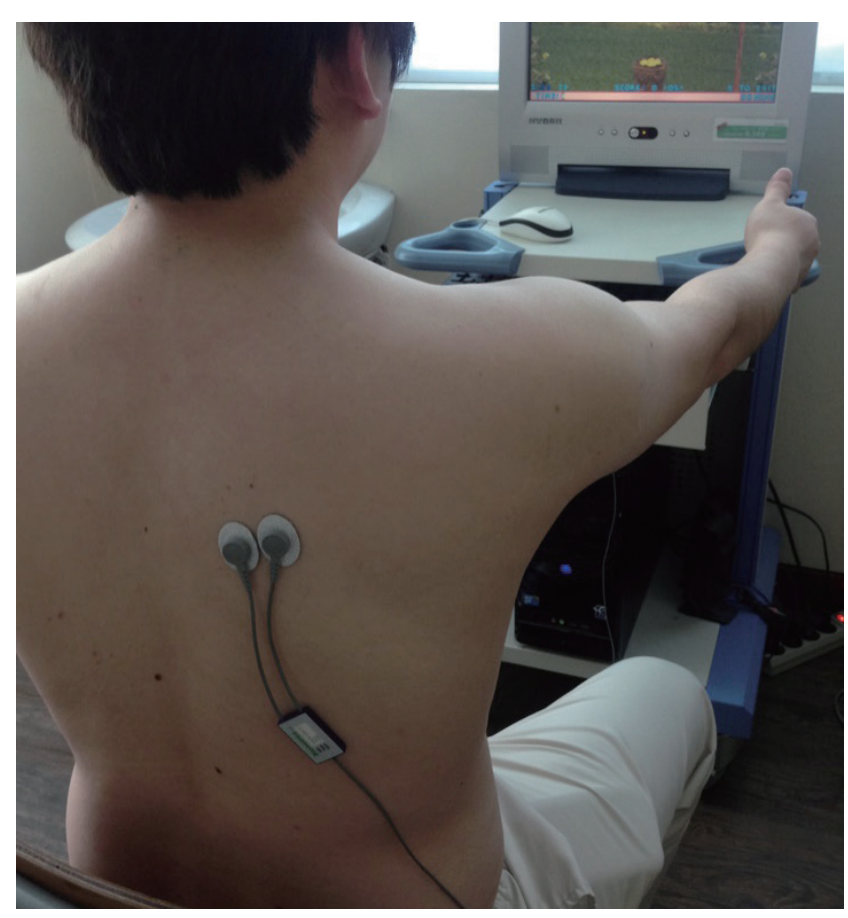

Figure 2. Location of recording electrode.

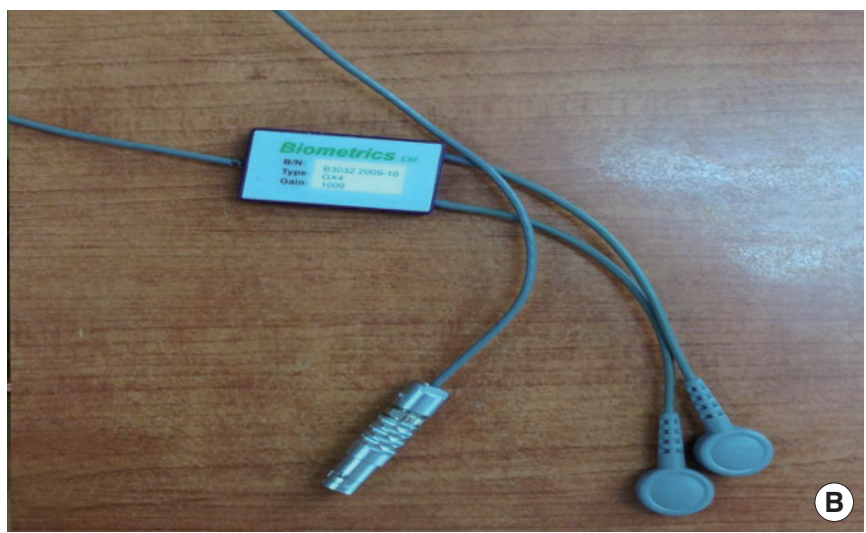

Figure 1. (A) E-LINK system, (B) Myo-Ex of E-LINK system. 
전 운동, 견갑골 안정화 신전 운동으로 구성하였다.

\section{3) 생체되먹임을 이용한 견갑골 안정화 운동}

E-LINK system의 Myo-Ex 기록전극을 아래등세모근에 부착한 뒤, 정 면에 있는 모니터를 주시하고 중재 훈련 과제 (축구 골 넣기 게임, 바나 나 따는 원숭이 게임, 지구 모형 따라가기 게임, 스키활강 게임)와 함께 견갑골 안정화 운동 (견갑골 안정화 외회전 운동, 견갑골 안정화 굴곡 운동, 견갑골 안정화수평외전 운동, 견갑골 안정화 신전 운동)을 시행 한다. 중재는 6 주간, 3 회/1주, 40 분/1일 동안 시행하였다(Figuer 2).

\section{3. 측정방법}

1) 표면 근전도 시스템

생체되먹임 견갑골 안정화 운동 전과 후의 상지의 근활성도 변화를 측정하기 위하여 MP100 (Biopac System, USA)을 이용하여 측정하였 으며, 전환된 디지털 신호는 개인용 컴퓨터에서 Acqknowledge 3.91 소 프트웨어를 이용하여 자료 처리하였다. 전극은 $\mathrm{Ag}-\mathrm{Ag} / \mathrm{Cl}$ (Biopac, $\mathrm{di}-$ ameter $2 \mathrm{~cm}$ )을 사용하여 측정하였으며 근전도의 신호는 $1,000 \mathrm{~Hz}$ 의 sampling rate의 신호 획득률로 수집한 후, Full-wave rectification 처리 하였다. 자료정리는 Acqknowledge 3.8.1 (Biopac System, USA) 소프트 웨어를 이용하여 30-500 Hz에서 구간필터링(band pass filtering)하고 잡음제거를 위해 $60 \mathrm{~Hz}$ 로 필터링하여 신호를 처리하였다. 아래등세 모근, 중간어깨세모근, 앞톱니근의 근활성도는 기능적 팔 뻗기 검사 를 3 회 검사하는 동안 3 회 측정하여 수집된 자료는 표준화하기 위하 여 측정된 raw data를 실효치(root mean square, RMS)로 변환하고 측 정된 RMS 값을 이용하여 평균값을 사용했다. 사전검사는 중재 전에 시행하였고, 사후검사는 6주 후시행하였다.

\section{2) 상지 기능 평가}

(1) 퓨글 마이어 상지 기능 검사(Fugl-Meyer Assessment, FMA)

$\mathrm{FMA}$ 는 뇌졸중 이후의 운동 기능, 균형, 감각과 관절 기능의 일부를 측정하는 평가 도구이다. 점수는 수행 능력에 따라 0-2 점을 부여하 는 데, 수행하지 못하는 경우 0 점, 부분적으로 수행하는 경우 1 점, 완 전하게 수행하는 경우 2점으로 평가한다. ${ }^{29} \mathrm{FMA}$ 항목 중 상지 검사 는 33 항목 으로 어깨/팔꿈치/아래팔 18 항목, 손목 5 항목, 손(손가락) 7 항목, 상지 협응능력 3 항목으로 되어 있다. FMA 상지 검사의 점수 는 총 66 점을 만점으로 어깨/팔꿈치/아래팔 36 점, 손목 10 점, 손(손 가락) 14 점, 상지 협응능력 6 점으로 되어 있다. FMA 전체 검사의 검 사자 간 및 검사자 내 신뢰도는 0.96 이고, 상지 검사의 검사자 간 및 검 사자내 신뢰도는 0.97 이다. ${ }^{29}$ 본 연구에서는 마비측의 측정값만 사용 하였다. 사전검사는 중재 전에 시행하였고, 사후검사는 6주 후 시행 하였다.
(2) 도수 기능 검사(Manual Function Test, MFT)

MFT는 뇌졸중 환자의 상지 기능을 객관적으로 평가하는 도구로써 회복 과정과 일상생활동작 능력을 실용적으로 측정하도록 고안된 평가 지표이다. MFT의 구성 항목은 상지의 운동, 쥐기 및 손가락 조 작의 세 가지 영역에 대해 각각 8 개 항목으로 구성되어 있으며 총 32 개 문항으로 구성되어 있다. 각 문항에 대한 점수는 수행할 수 없을 경우 0 점, 완전히 수행한 경우 1점으로 총 32점이 만점이고, MFS (Manual Function Score)는 MFT의 만점인 32점을 3.125배 하여 100 점 으로 해서 사용한다. 이 평가도구의 타당도와 신뢰도는 모두 0.95 이 다. ${ }^{30}$ 사전검사는 중재 전에 시행하였고, 사후검사는 6 주 후 시행하였 다.

\section{4. 자료분석}

본 연구의 결과 분석은 Window SPSS 18.0 프로그램을 이용하여 처리 하였다. 연구대상자의 동질성 검증을 위해 독립표본 t-검정(independent t-test)을 실시하였고, 중재방법에 따른 근활성도와 상지 기능을 비교하기 위하여 공분산분석(analysis of covariance, ANCOVA)을 실 시하였다. 통계학적 유의 수준은 $\alpha=0.05$ 로 하였다.

\section{결 과}

\section{1. 근활성도 비교}

그룹 간의 중재 전후 아래등세모근 근활성도 비교에서 실험군은 $37.62 \pm 1.68 \mu \mathrm{V}$ 에서 $42.00 \pm 2.00 \mu \mathrm{V}$ 로 중간어깨세모근 근활성도 비교 에서 $41.50 \pm 2.44 \mu \mathrm{V}$ 에서 $44.37 \pm 1.86 \mu \mathrm{V}$ 로 앞톱니근 근활성도 비교에 서 $34.25 \pm 1.48 \mu \mathrm{V}$ 에서 $37.62 \pm 1.68 \mu \mathrm{V}$ 로 대조군과 비교하여 통계학적 으로 유의한 차이가 있었다 $(\mathrm{p}<0.05)$ (Table 2).

\section{2. 상지 기능 비교}

그룹 간의 중재 전후 상지 기능 비교에서 실험군의 FMA는 $33.25 \pm 1.90$ score에서 $37.12 \pm 1.88$ score로 MFT는 $16.8 \pm 1.60$ score에서 $22.37 \pm 2.50$ score로 대조군과 비교하여 통계학적으로 유의한 차이가 있었다 $(\mathrm{p}<0.05)$ (Table 3).

\section{고 찰}

본 연구에서는 6 주간 생체되먹임 견갑골 안정화 운동이 상지의 근활 성도와상지 기능에 미치는 영향을 알아보고자 본 연구를 실시하였다. 뇌졸중 환자의 상지 기능 회복은 일상생활 수행의 필수적인 요소 로서 가족과 사회 구성원으로의 복귀를 위해 중요한 지표가 된다. ${ }^{31}$ 뇌졸중 환자 $69 \%$ 이상이 상지의 기능적 운동장애를 경험한다. 상지 
Table 2. Comparison of muscle activity between group

\begin{tabular}{|c|c|c|c|c|c|c|}
\hline \multirow{3}{*}{ Test } & \multicolumn{2}{|c|}{ Pre-test } & \multicolumn{2}{|c|}{ Post-test } & \multirow{3}{*}{$\mathrm{F}$} & \multirow{3}{*}{$\mathrm{p}^{+}$} \\
\hline & Experiment & Control & Experiment & Control & & \\
\hline & \multicolumn{2}{|c|}{ Mean $\pm S D$} & \multicolumn{2}{|c|}{ Mean \pm SD } & & \\
\hline LT & $37.62 \pm 1.68$ & $36.87 \pm 1.95$ & $42.00 \pm 2.00$ & $39.25 \pm 1.48$ & 7.061 & $0.026^{*}$ \\
\hline DM & $41.50 \pm 2.44$ & $41.12 \pm 2.41$ & $44.37 \pm 1.86$ & $42.75 \pm 2.91$ & 5.209 & $0.045^{*}$ \\
\hline SA & $34.25 \pm 1.48$ & $33.37 \pm 1.50$ & $37.62 \pm 1.68$ & $35.37 \pm 1.50$ & 8.714 & $0.036^{*}$ \\
\hline
\end{tabular}

Values are presented as mean \pm standard deviation.

LT: Lower Trapezius, DM: Deltoid Middle, SA: Serratus Anterior.

$\mathrm{p}^{+}$: Analysis of covariance, ${ }^{*} \mathrm{p}<0.05$.

Table 3. Comparison of function of the upper extremity ability between group

\begin{tabular}{|c|c|c|c|c|c|c|}
\hline \multirow{3}{*}{ Test } & \multicolumn{2}{|c|}{ Pre-test } & \multicolumn{2}{|c|}{ Post-test } & \multirow{3}{*}{$\mathrm{F}$} & \multirow{3}{*}{$\mathrm{p}^{+}$} \\
\hline & Experiment & Control & Experiment & Control & & \\
\hline & \multicolumn{2}{|c|}{ Mean $\pm S D$} & \multicolumn{2}{|c|}{ Mean士SD } & & \\
\hline FMA & $33.25 \pm 1.90$ & $32.37 \pm 1.76$ & $37.12 \pm 1.88$ & $35.00 \pm 2.39$ & 10.927 & $0.021^{*}$ \\
\hline MFT & $16.8 \pm 1.60$ & $18.37 \pm 1.99$ & $22.37 \pm 2.50$ & $21.25 \pm 2.12$ & 7.878 & $0.004^{*}$ \\
\hline
\end{tabular}

Values are presented as mean \pm standard deviation.

FMA: Fugl-meyer assessment, MFT: Manual function test.

$\mathrm{p}^{+}$: Analysis of covariance, ${ }^{*} \mathrm{p}<0.05$.

운동장애는 근력 약화, 비정상적 근 긴장도, 어깨 복합체에서 가동성 부족, 수의적 움직임 수행 시 근육의 불균형과 비협응 등으로 발생된 다. ${ }^{32}$ 상지의 운동장애는 손의 조작력과 기능적인 팔의 사용을 제한 하여 삶의 질 저하와 기능적 독립의 어려움을 야기한다. ${ }^{31}$ 뇌졸중 환 자의 상지 기능 회복을 위해 다양한 연구들이 진행되었지만, 마비측 상지의 움직임을 통한 운동학적 중재방법 수행의 강조는 신체적 기 능 수준이 저하된 환자들에게 동기부여의 감소와 과제수행의 어려 움을 겪게 한다. 최근에는 이러한 중재 방법들을 보완하여 다양한 감 각 되먹임을 통하여 과제 성취에 대한 동기 유발과 능동적 참여를 가 능하게 하고, 환자의 기능향상에 필요한 다양한 과제를 집중적으로 훈련시킬 수 있는 생체되먹임 훈련이 제시되고 있다.33

본 연구 결과는 근활성도에서 아래등세모근, 중간어깨세모근, 앞 톱니근에서 실험군과 대조군 모두 전후 유의한 차이를 보였지만, 실 험군에서 더 효과적이었다. 또한 상지 기능 평가에서 모두 전후 유의 한차이를 보였지만, 실험군에서 더 효과적이었다.

Basurt 등 34 은 충돌 증후군을 가진 환자 40 명을 대상으로 견갑골 안정화 운동을 적용한 그룹에서 견갑골 자세 변화와 상지의 근활성 도가 증가한다고 보고하였다. 본 연구에서도 견갑골 중재를 적용한 그룹에서도 상지의 근활성도가 통계학적으로 유의한 차이를 보였다. 연구 대상이 견관절 충돌 증후군 환자이고, 본 연구 대상은 뇌졸중 환자이다. 하지만 견갑골 충돌 증후군은 견갑골의 비정상적인 위치 와 근 불균형으로 견갑골의 안정성과 움직임에 영향을 미친다. 뇌졸 중 환자들도 견갑골 충돌 증후군 환자와 마찬가지로 부적절한 견갑 골 움직임으로 인해 견갑골 주변의 근육들의 약화를 일으켜 안전성
에 영향을 미치게 된다. Jung $g^{28}$ 은 승모근 근막 통증 증후군 환자 30 명 을 대상으로 견갑골 안정화 운동을 적용한 그룹에서 어깨 기능과 아 래등세모근, 전거근 근활성도에서 유의한 차이를 보였다. 본 연구에 서도 견갑골 안정화 운동을 이용한 그룹이 아래등세모근과 앞톱니 근에서 통계적으로 유의한 증가를 보였다. 연구 대상이 근막 통증 증 후군 환자이고 본 연구 대상은 뇌졸중 환자이지만, 근막 통증 증후군 환자들도 뇌졸중 환자들과 마찬가지로 견관절 주변의 비정상적인 작 용과 근육 동원으로 인해 견갑골의 자세 이상을 유발하여 움직임 제 한과 함께 견관절에서 발생되는 힘에 악영향을 주는 공통된 점이 있 다. 본 연구에서는 대상이 뇌졸중 환자이기 때문에 근활성도 값의 향 상 정도가 더 작았을 것으로 사료된다. Jung ${ }^{26}$ 은 뇌졸중 환자를 16 명 을 대상으로 견갑골 훈련과 전통적인 물리치료를 비교한 연구를 하 였는데, 견갑골 훈련을 적용한 그룹에서 상지 기능과 일상생활활동 수행 능력에서 통계적으로 유의한 증가를 보였다. 본 연구에서도 견 갑골 안정화 운동을 이용한 그룹에서 상지 기능이 향상되는 동일한 결과를 얻었다. 이는 견갑골 안정화 운동을 통해 견갑골의 위치가 최 적의 위치에 놓임으로서 안정성을 제공하여, 상지의 수의적인 움직 임 이전에 견갑골 주위 근육들의 조절 능력 향상으로 상지 기능을 향상시킨 것으로 생각된다. $\mathrm{Yoo}^{35}$ 는 뇌졸중 환자 40 명을 대상으로 연 구한 결과, 견갑골 안정성의 증가는 뇌졸중 환자의 상지 기능에 유의 한 증가를 보였다. 본 연구에서도 견갑골 안정화 운동을 이용한 그룹 에서 상지 기능이 향상되는 동일한 결과를 얻었다. 이는 견갑골 안정 화운동을 통해 주변 근육 힘들이 균형을 유지함으로써, 견갑골을 안 정화시켜 상지의 기능을 향상시킨 것으로 생각된다. $\mathrm{Moon}^{36}$ 은 유방 
절제술 환자를 대상으로 견갑골 안정화 운동을 중재한 결과, 상지 기 능에서 통계적으로 유의한 차이를 보였다. 본 연구에서도 견갑골 안 정화를 이용한 그룹에서 상지 기능이 통계적으로 유의한 차이를 보 였다. 유방절제술을 시행한 환자들은 수술 후 근육 및 신경 손상으로 인하여 수술부위, 어깨 관절, 어깨 주변 근육 및 힘줄의 약화로 상지 기능이 저하되어 일상생활이 제한되는 신체적 문제점을 갖고 있다. 뇌졸중 환자들도 마비측의 근육의 변화와 감각 손상으로 인해 일상 생활동작 수행 능력에 영향을 미친다.

$\mathrm{Jo}^{27}$ 는 중추 신경 발달 치료와 견갑골 훈련을 병행한 그룹에서 운 동 평가 척도, 도수 기능 검사, 기능적 독립척도에서 유의한 증가를 보 였다. 이는 뇌졸중 환자들은 중추 신경 발달 치료와 함께 견갑골 훈 련이 필요하다는 것을 뒷받침해 줄 수 있다. $\mathrm{Ana}^{37}$ 는 뇌졸중 환자에 게 견갑골 중재는 상지의 근력과 기능적 회복의 질 향상을 제공한다 고 보고하여 본 연구와 일치하는 결과를 보였다. Song 등 38 은 뇌졸중 환자 27명을 대상으로 비디오 게임을 기반으로 한 가상현실 훈련과 일반적인 재활치료를 비교한 연구를 하였는데, 비디오 게임을 기반 으로 한 가상현실 훈련을 이용한 그룹에서 상지 근력과 상지 기능에 서 유의한 차이를 보였다. 본 연구에서도 생체되먹임 견갑골 안정화 운동을 이용한 그룹에서 상지의 근활성도와 기능이 향상되는 동일 한 결과를 얻었다. $\mathrm{Seo}^{39}$ 는 뇌졸중 환자 20 명을 대상으로 생체되먹임 을 이용한 증강현실 훈련을 중재한 결과, 상지 기능에서 유의한 차이 를 보였다. 본 연구에서도 생체되먹임 견갑골 안정화 운동을 이용한 그룹에서 상지 기능이 향상 되는 동일한 결과를 얻었다. 이는 과제를 수행하는 동안 자신의 움직임에 대한 정보가 제공되어, 다음 움직임 수행에서 즉각적인 행동수정을 이끄는 긍정적인 강화로 사용되어 상 지 기능이 향상된 것으로 사료된다.

$\mathrm{Kim}^{40}$ 은 뇌졸중 환자 20 명을 대상으로 로봇을 이용한 게임 훈련과 일반적인 상지 재활치료를 비교한 연구를 하였는데, 로봇을 이용한 게임 훈련그룹에서 상지 근력과 상지 기능 검사에서 유의한 차이를 보였다. 본 생체되먹임을 이용한 그룹에서 동일한 결과를 얻었다. 이 는 생체되먹임이 목표를 달성하고자 노력하는 방법을 직접 보여주고, 그에 따른 동기부여를 제공하여 향상된 것으로 사료된다.

향후 본 연구를 바탕으로 어깨에 기능 이상을 가진 운동선수들에 게 생체되먹임 견갑골 안정화 운동을 이용한 중재가 근활성도와 운 동 수행 능력에 대한 연구를 실시해 보는 것이 필요할 것이다.

본 연구는 뇌졸중 환자들을 대상으로 생체되먹임 견갑골 안정화 운동을 6 주간 실시한 후 상지의 근활성도와 상지 기능에 미치는 영 향을 분석하여 생체되먹임 견갑골 안정화 운동의 효과를 알아 보았 다. 아래등세모근, 중간어깨세모근, 앞톱니근의 근활성도(RMS)값의 분석을 통하여 생체되먹임 견갑골 안정화 운동이 과제지향적인 운 동보다 근활성도를 증가시키기 위해 더 효과적임을 증명하였다. 또한
퓨글마이어 상지기능검사와 도수기능검사를 통하여 생체되먹임 견 갑골 안정화 운동이 과제지향적 물리치료보다 상지 기능을 증가시키 기 위해 더 효과적임을 증명하였다. 그러므로 생체되먹임 견갑골 안 정화 운동이 과제지향적 물리치료보다 근활성도와 상지 기능의 능 력을 향상시키는 것으로 결론을 얻었다.

\section{ACKNOWLEDGEMENTS}

The Research has been conducted by the Research Grant of Sehan University in 2015.

\section{REFERENCES}

1. Lee MS, Lee JH, Park SK et al. The effect of ankle joint taping applied to patients with hemi-plegia on their gait velocity and joint angles. J Kor Phys Ther. 2012;24(2):157-62.

2. Jung JH, Kim JH. Correlation between bilateral reciprocal leg press test and The balance in chronic stroke patient. J Kor Phys Ther. 2013;25(4): 180-6.

3. Jung MS, Park JW. The relationship between balance test and fear of falling in community dwelling elderly. J Kor Phys Ther. 2012;24(1):23-8.

4. Park S, Patten C. Strengthening to promote functional recovery poststroke: An evidence-based review. Top Stroke Rehabil. 2008;15(3):17799.

5. Timmermans AA, Spooren A, Kingma H et al. Influence of task-oriented training content on skilled arm-hand performance in stroke: a systematic review. Neurorehabilitation and Neural Repair. 2010;24(9):858-70.

6. Matoki N, Sato Y, Satoh K. Muscular atrophy in the hemiplegic thigh in patients after stroke. Am J Phys Med Rehabil. 2003;81(11):862-5.

7. Patten C, Lexell J, Brown HE. Weakness and strength training in persons with poststroke hemiplegia: Rationale, method, and efficacy. Journal of Rehabilitation Research and Development. 2004;41(3A):293-312.

8. Matoki N, Sato Y, Satoh K. Muscular atrophy in the hemiplegic thigh in patients after stroke. Am J Phys Med Rehabil. 2003;81(11):862-5.

9. Gonzalez J, Horiuchi Y, Wenwei Y. Classification of upper limb motions from around shoulder muscle activities: Hand biofeedback. The open Medical Informatics Journal. 2010;4:74-80.

10. Cools AM, Declercq GA, Cambier DC. Trapezius activity and intramuscular balance during isokinetic exercise in overhead athletes with impingement syndrome. Scand J Med Sports. 2007;17(1):25-33.

11. Ludewig PM, Hoff MS, Osowski EE. Relative balance of serratus anterior and upper trapezius muscle activity during push up exercise. Am J Sports Med. 2004;22(2):484-93.

12. Jones MAB, Rivett DA. Clinical reasoning for manual therapists. London, Butterworth Heinemann, 2004;106.

13. Langhorne P, Gallacher K, Morrisin D. Uncovering treatment burden as a key concept for stroke: Asystematic review of qualitative research. PLoS Med. 2013;10(6):e1001473.

14. Michael KM, Shaughnessy M. Stroke prevention and management in older adults. J Cardiovasc Nurs. 2006;21(5 Suppl 1):S21-S26. 
15. Kwakkel G, Kollen B, Predicting improvement in the upper paretic limb after stroke: A longitudinal prospective study. Restor Neurol Neuro sci. 2007;25(5-6):454-60.

16. Carr JH, Shepherd RB. Enhancing physical activity and brain reorganization after stroke. Neurol Res Int. 2011;3:1-7.

17. Schaechter JD, Kraft E, Hilliard TS. Motor recovery and cortical reorganization after constraint induced movement therapy in stroke patients: A preliminary study. Neurorehabil Neural Repair. 2002;16(4):326-38.

18. Whitall J, Waller SM, SilverKH. Repetitive bilateral arm training with rhythmic auditory cueing improves motor function in chronic hemiparetic stroke. Stroke. 2000;31(10):2390-5.

19. Prange GB, Jannink MJ, Groothuis-Oudshoorn CG. System review of the effect of robot aided therapy on recovery of the hemiparetic after stroke. JRRD. 2006;43(2):171-84.

20. Katz LM, Sender IO, Dvir Z. The influence of early cyling training on balance in stroke patients at the subacute stage. Clin rehabil 2006;20;298405.

21. Lum PS, Burgar CG, Shor PC. Robot assisted movement training compared with conventional therapy techniques for the rehabilitation of upper limb motor function after stroke. Arch Phys Med Rehabil. 2002;83; 952-9.

22. Forkan R, Pumper B, Smyth N, Exercise adherence following physical therapy intervention in older adults with impaired balance. Phys Ther. 2006;86(3):401-10.

23. Leroux A, Pinet II, Nadeau S. Task-oriented intervention in chronic stroke: Changes in clinical and laboratory measures of balance and mobility. Am J Phys Med Rehabil. 2006;85(10):820-30.

24. Kirkesola F. SET advanced level 2-U, the upper body, course book. Norway: SET kompetance AS, 2004;3-17.

25. Jang JH, Lee HO, Koo BO. Treatment approach for the movement dysfunction of the shoulder girdle. J Kor Phys Ther. 2003;15(4):412-30.

26. Jung KM. The effect of scapula setting intervention on the function of upper extremity, balance, and walking in the patients with stroke. Wonkwang University. Dissertation of Master's Degree. 2010.

27. Jo MA, An effect of scapula setting on upper extremity functions and activities of daily living of chronic stroke patients. Daegu University. Dissertation of Master's Degree. 2011.
28. Jung KH. The effect of scapula stability exercise on pain, function and muscle activation in patients with myofacial pain syndrome. Chungju University. Dissertation of Master's Degree. 2012.

29. Deakin A, Hill H, Pomeroy V. Rough guide the fugl-meyer assessment: upper limb section. Physiotherapy. 2003;89(12):751-63.

30. Miyamoto, Sayaka MSC, Kondo. Reliability and validity of the manual function test in patients with stroke. American Journal of Physical Medicine \& Rehabilitation. 2009;88(3):247-55.

31. Kamper DG, Mckenna-cole AN, Kahn LE. Alterations in reaching after stroke and their relation to movement direction and impairment severity. Archives of Physical Medicine and Rehabilitation. 2002;83(5):702-7.

32. Cristea MC, Pitito A, Levin MF. Arm reaching improvements with short term practice depend on the severity of the motor deficit in stroke. Exp Brain Res. 2003;152(4):476-88.

33. Daniel PB, Wii-habilitation: in there a role in trauma?. Injury. 2010;41: 671-3.

34. Baskurt Z, Baskurt F, Gelecek N. The effectiveness of scapular stabilization exercise in the patients with subacromial impingement syndrome. J Back Musculoskeletal rehabil. 2011;23(3):173-9.

35. Yoo YY. The effect of scapular stability in anatomical position for arm reaching and shoulder motion in hemipegic patient. Gachon University. Dissertation of Master's Degree. 2007.

36. Moon SJ. The effect of scapular stabilization exercise on shoulder joing range of motion, arm function after diverse mastectmies. Dankook University. Dissertation of Master's Degree. 2014.

37. Ana IA. Scapula setting stability versus mobility. MCs in Neurological Physiotherapy. 2014;11:1-3.

38. Song CH, Seo SM, Lee KJ. Video game based exercise for upper extremity function, strength, visual perception of stroke patients. Journal of special education \& rehabilitation science. 2011;50(No. 1):155-180.

39. Seo JM. Effect of augmented reality training on upper extremity function, stress and self-esteem of stroke patients. Dongshin University. Dissertation of Master's Degree. 2014.

40. Kim JW. The Effect of robot assisted game training on upper extremity function in stroke patients. Donga University. Dissertation of Master's Degree. 2015. 